\title{
RANCANG BANGUN MESIN PERONTOK LADA (Piper Nigrum L.) TIPE SILINDER PERONTOK BERJARING
}

\author{
Suhendra, Yogi Hardi, Feby Nopriandy, dan Irma Fahrizal Butsinignsih \\ Jurusan Teknik Mesin, Politeknik Negeri Sambas \\ Email: aka.suhendra@yahoo.com
}

\begin{abstract}
ABSTRAK
Lada hitam dihasilkan dari buah tanaman lada yang diproses dengan cara dirontok dan dikeringkan. Proses perontokan dapat dilakukan secara manual atau mekanis. Proses perontokan lada secara manual memiliki banyak kelemahan sehingga perlu dikembangkan sistem perontokan lada secara mekanis. Sistem perontokan yang didesain harus sesuai dengan kebutuhan petani lada yang umumnya adalah petani dengan luas lahan sempit. Mesin perontok lada tipe silinder perontok berjaring merupakan upaya untuk mengatasi permasalahan ini karena mesin memiliki konstruksi sederhana, murah dan terbuat dari bahan yang mudah diperoleh. Tujuan penelitian yang dilakukan adalah merancang bangun dan menguji kinerja mesin perontok lada dengan mekanisme perontok berupa silinder perontok berjaring. Variabel bebas dalam pengujian adalah kekuatan tarik pegas sedangkan variabel tak bebas adalah kapasitas, efisiensi perontokan dan tingkat kerusakan buah lada. Pelaksanaan penelitian dilakukan dengan melakukan perancangan dan pembuatan komponen, dilanjutkan dengan melakukan pengujian. Hasil rancang bangun diperoleh mesin perontok lada tipe silinder perontok berjaring berpenggerak motor listrik 1/4 HP, kecepatan putar silinder perontok 339 $\mathrm{rpm}$, sistem transmisi sabuk V dan puli, massa mesin $12 \mathrm{~kg}$, panjang $50,0 \mathrm{~cm}$, lebar $38,5 \mathrm{~cm}$ dan tinggi $68 \mathrm{~cm}$. Hasil pengujian menunjukkan bahwa semakin kecil kekuatan tarik pegas dapat meningkatkan kapasitas perontokan lada. Sebaliknya, semakin besar kekuatan tarik pegas dapat meningkatkan efisiensi perontokan dan persentase kerusakan buah lada. Kapasitas dan persentase kerusakan buah lada tertinggi diperoleh pada kekuatan tarik pegas $0,19 \mathrm{~kg} / \mathrm{cm}$ dengan kapasitas 117,8 $\mathrm{kg} / \mathrm{jam}$ dan persentase kerusakan $8,8 \%$, sedangkan efisiensi perontokan tertinggi diperoleh pada kekuatan tarik pegas $0,45 \mathrm{~kg} / \mathrm{cm}$ yaitu sebesar $97,5 \%$ Kata kunci-lada; perontokan; silinder berjaring, uji kinerja
\end{abstract}

\section{PENDAHULUAN}

Lada merupakan jenis tanaman rempah yang banyak dibudidayakan di Indonesia. Sentra utama produksi lada terdapat di daerah Lampung, Bangka Belitung, Kalimantan Barat, Kalimantan Timur, Bengkulu dan Sumatera Selatan (Winarti dan Nurdjannah, 2007). Produksi utama tanaman lada adalah lada hitam dan lada putih. Perbedaan produksi lada tersebut terdapat pada proses pengolahannya. Lada hitam diperoleh dari buah tanaman lada yang masih hijau, diproses dengan cara dirontok dan dikeringkan, sedangkan lada putih dihasilkan dari buah lada yang telah tua berwarna merah atau kuning, selanjutnya direndam, dikupas kulitnya dan dikeringkan atau dijemur.

Proses perontokan memiliki peran penting dalam produksi lada hitam. Perontokan lada untuk memproduksi lada hitam dapat dilakukan dengan cara manual atau mekanis. Perontokan secara manual dilakukan dengan menginjak-injak buah lada menggunakan kaki atau memipil buah lada menggunakan tangan. Kelemahan perontokan lada secara manual adalah tidak efisien, kapasitas perontokan rendah dan buah lada yang agak tua akan mudah rusak jika dirontok dengan cara diinjakinjak. Menurut Mislaini (2016), faktor teknis seperti cara perontokan mempengaruhi kadar kotoran produk yang dirontok.

Upaya perontokan lada secara mekanis telah banyak dilakukan untuk mengatasi masalah perontokan lada secara manual. Hidayat dkk (2001), membuat perontok lada tipe aksial menggunakan bandul getar memiliki kapasitas 267,46 kg/jam dengan efisiensi perontokan 98,7\%. Yunus (2007), merancang bangun mesin perontok lada dengan penggerak motor bensin berdaya 6,5 HP memiliki kapasitas perontokan 5,7 kg/menit dengan efisiensi 97,7\%. Djajasukmana (2010), merancang bangun mesin perontok lada tipe poros asentris berpenggerak motor bensin 5,5 HP dengan kapasitas perontokan $600 \mathrm{~kg} / \mathrm{jam}$, efisiensi perontokan $98,74 \%$ dan tingkat kerusakan lada 2,24\%. Sugianto dan Sukanto (2012), merancang bangun mesin perontok lada yang memiliki kapasitas perontokan 40 
$\mathrm{kg} / \mathrm{jam}$ dengan efisiensi perontokan 80\%. Satria dan Suhendra (2014), merancang bangun mesin perontok lada dengan penggerak pedal berkapasitas $30-40 \mathrm{~kg} / \mathrm{jam}$.

Beberapa mesin perontok lada yang telah dibuat menggunakan motor penggerak berdaya besar. Guna menyesuaikan kebutuhan petani lada di Kabupaten Sambas yang umumnya adalah petani dengan luas lahan yang sempit maka perlu dirancang bangun mesin perontok lada sederhana dengan penggerak motor berdaya kecil. Konsep teknologi tepat guna yaitu mudah dibuat, murah dan sederhana diterapkan dalam rancang bangun mesin perontok lada ini. Penggunaan bahan-bahan yang murah dan mudah diperoleh seperti kayu dan jaring sebagai mekanisme perontok lada merupakan keunggulan pada mesin perontok yang akan dirancang bangun. Hal ini memungkinkan biaya yang dibutuhkan untuk memproduksi dan merawat mesin perontok lada ini menjadi relatif murah.

Konsep awal desain mesin perontok yang dirancang bangun merupakan pengembangan dari mesin perontok lada dengan penggerak pedal hasil desain Satria dan Suhendra (2014). Sumber penggerak mesin perontok lada dengan penggerak pedal masih menggunakan tenaga manusia. Besarnya kapasitas perontokan tergantung operator dalam memutar silinder perontok. Efisiensi perontokan sangat dipengaruhi oleh besarnya kekuatan tarik pegas pada pemisah buah dan tangkai.

Tujuan penelitian yang dilakukan adalah merancang bangun mesin perontok lada dengan mekanisme perontok berupa silinder berjaring berpenggerak motor listrik, serta melakukan uji kinerja kekuatan tarik pegas terhadap kapasitas, efisiensi perontokan dan tingkat kerusakan pada buah lada. Mesin perontok lada hasil rancang bangun diharapkan dapat membantu petani dalam proses perontokan lada.

\section{METODOLOGI PENELITIAN}

\section{A. Waktu dan Tempat Penelitian}

Waktu pelaksanaan penelitian dimulai dari bulan Maret sampai dengan Juni 2019. Tempat pembuatan mesin perontok lada dilakukan di bengkel mesin perkakas dan bengkel las Politeknik Negeri Sambas, Kalimantan Barat.

\section{B. Perancangan Mesin Perontok Lada}
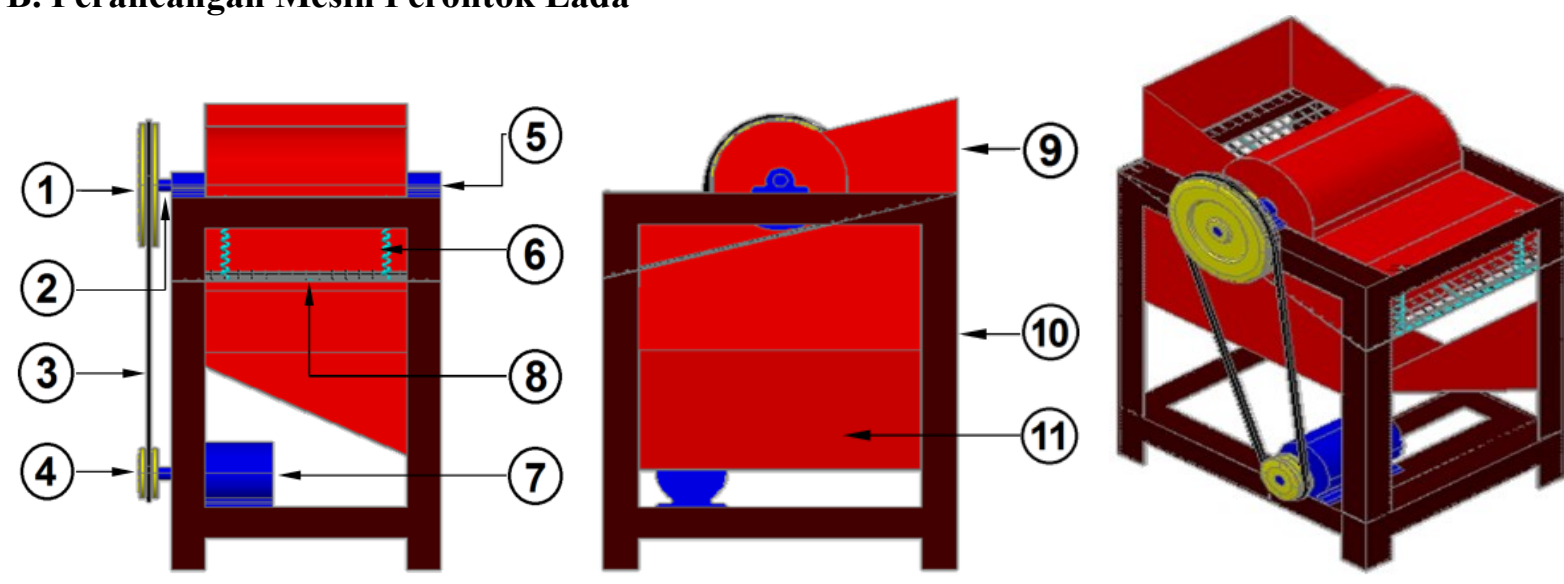

Gambar 1. Desain mesin perontok lada

Keterangan :
1. Puli pada silinder perontok
2. Poros
3. Sabuk
4. Puli motor penggerak
5. Bantalan
6. Pegas

7. Motor penggerak

8. Pemisah buah dan tangkai

9. Hopper

10. Rangka

11. Saluran keluar lada

Bentuk awal desain mesin perontok lada dapat dilihat pada Gambar 1. Perancangan mesin perontok lada diawali dengan mengukur besarnya gaya perontokan pada buah lada untuk mendapatkan nilai torsi yang diperlukan mesin perontok. Alat yang digunakan untuk mengukur besarnya gaya perontokan adalah neraca pegas. Kegiatan berikutnya adalah melakukan perancangan 
berturut-turut pada daya motor, diameter poros, ukuran puli, jenis sabuk, jarak sumbu poros, kapasitas sabuk dan jumlah sabuk.

\section{Pembuatan Mesin Perontok Lada}

Alat yang diperlukan untuk membuat mesin perontok lada adalah mesin bubut, mesin bor, las listrik, gerinda tangan, pemotong plat, staples, mesin penekuk dan pengerol. Bahan yang diperlukan adalah jaring, besi siku $3 \times 3 \mathrm{~cm}$, besi poros, silinder kayu, bantalan, motor listrik, puli, sabuk V, pelat $0,8 \mathrm{~mm}$, cat, baut $8 \mathrm{~mm}$ dan baut $10 \mathrm{~mm}$. Komponen utama mesin perontok lada yang dibuat adalah rangka, pemisah buah dan tangkai, poros silinder, silinder perontok, hopper dan saluran keluar lada. Langkah pembuatan mesin perontok lada tipe silinder perontok berjaring adalah sebagai berikut :

1. Pembuatan rangka

Bahan yang digunakan dalam pembuatan rangka adalah besi siku ukuran $3 \times 3 \mathrm{~cm}$. Penyambungan rangka dilakukan dengan cara dilas. Rangka dibuat dengan ukuran panjang, lebar dan tinggi masing-masing $50 \times 38,5 \times 56,5 \mathrm{~cm}$.

2. Pembuatan pemisah buah dan tangkai

Bahan yang digunakan dalam pembuatan pemisah buah dan tangkai lada adalah plat strip dengan tebal 1,5 mm dan jaring kawat berbentuk kotak $1,3 \times 1,3 \mathrm{~cm}$. Rangka pemisah buah yang terbuat dari plat strip disambung dengan cara dilas sedangkan jaring kawat dipasang pada rangka dengan cara diikat menggunakan kawat.

3. Pembuatan silinder perontok

Bahan yang digunakan dalam pembuatan silinder perontok adalah kayu dan jaring nilon. Bentuk kayu tersebut menjadi silinder bulat berdiameter $10 \mathrm{~cm}$ dengan panjang $30 \mathrm{~cm}$ dengan cara dibubut. Bor bagian tengah silinder menggunakan mata bor berdiameter $15 \mathrm{~mm}$ dan lilitkan jaring pada silinder lalu distaples untuk mengikat jaring pada silinder.

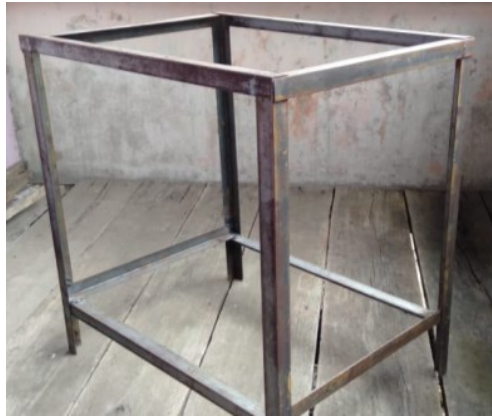

(a)

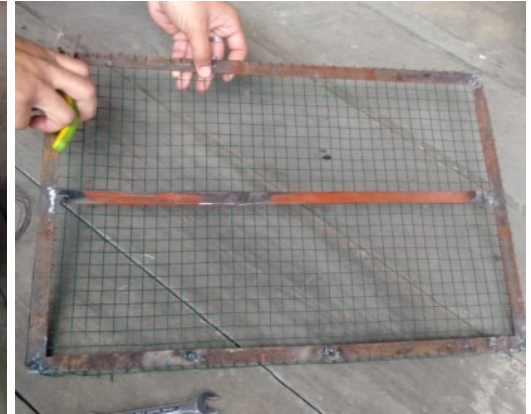

(b)

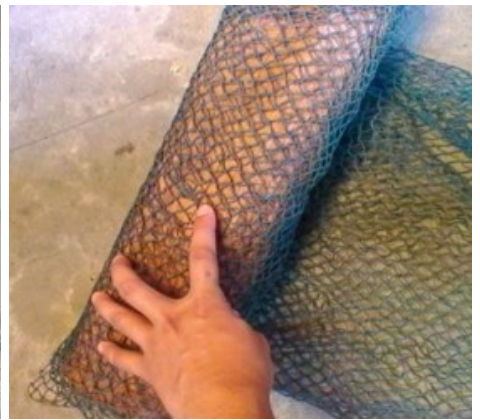

(c)

Gambar 2. (a) Rangka, (b) Pemisah buah dan tangkai, (c) Silinder perontok berjaring

4. Pembuatan poros silinder perontok

Poros silinder dibuat dari bahan baja karbon rendah menggunakan mesin bubut yang dibentuk menjadi berdiameter $15 \mathrm{~mm}$ dan panjang $45 \mathrm{~cm}$.

5. Pembuatan hopper dan saluran keluar buah lada

Hopper dan saluran keluar buah lada dibuat dari bahan pelat $0,8 \mathrm{~mm}$. Tahapan dalam pembuatannya dimulai dengan membuat pola gambar pada plat, memotorng plat, melakukan penekukan dan pengerolan.

6. Perakitan komponen.

Langkah-langkah dalam perakitan mesin perontok lada ini adalah sebagai berikut :

a. Pasang poros pada silinder perontok

b. Pasang bantalan pada rangka

c. Pasang poros dan silinder perontok pada bantalan

d. Pasang puli pada poros silinder perontok dan motor penggerak

e. Pasang motor penggerak pada rangka

f. Pasang sabuk V pada puli

g. Pasang pemisah buah dan tangkai

h. Pasang saluran keluar buah dan hopper 

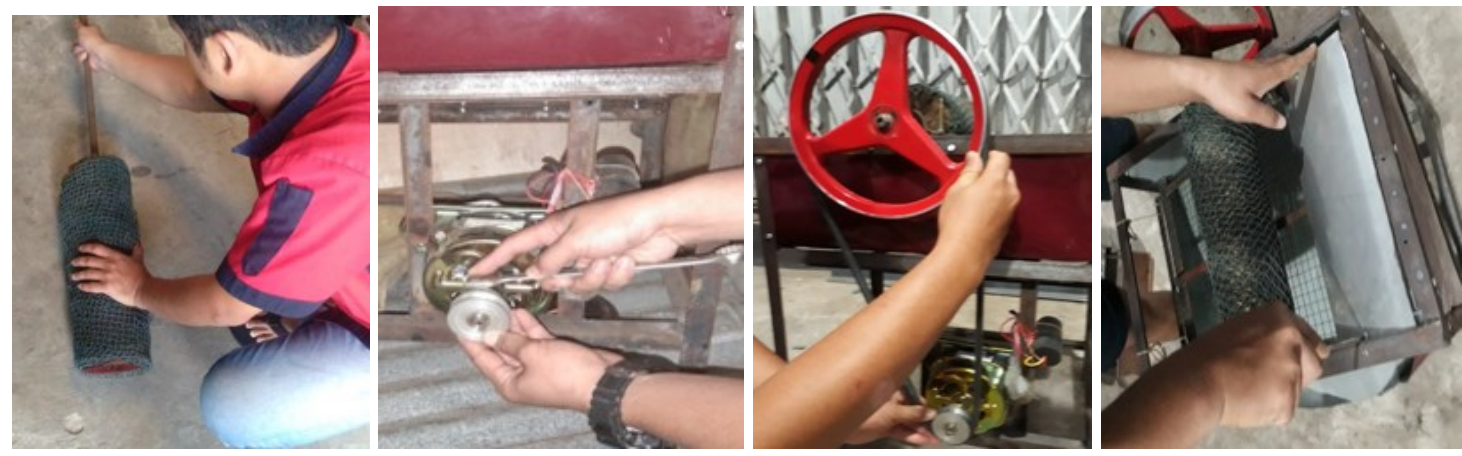

Gambar 3. Perakitan komponen mesin perontok lada

\section{Pengujian Mesin Perontok Lada}

Uji fungsional perlu dilakukan pada mesin perontok lada hasil rancang bangun untuk mengetahui kapasitas kerja dan efisiensi perontokan lada. Alat dan bahan yang diperlukan dalam pengujian mesin perontok adalah buah lada segar, timbangan, stopwatch dan wadah lada. Variabel bebas yang digunakan dalam pengujian ini adalah kekuatan tarik pegas pada pemisah buah lada yang divariasikan menjadi 3 perlakuan. Hasil pengujian selanjutnya dianalisis untuk menentukan kekuatan tarik pegas terbaik yang akan digunakan pada mesin perontok lada.

Kapasitas perontokan adalah banyaknya massa lada yang terontok dalam satuan waktu. Besarnya kapasitas perontokan lada dapat dihitung dengan persamaan 1.

Kapasitas $=\frac{m}{t}(\mathrm{~kg} / \mathrm{jam})$

keterangan:

$\mathrm{m}$ = Massa lada yang keluar dari mesin perontok $(\mathrm{kg})$

$\mathrm{t}$ = Waktu yang diperlukan dalam proses perontokan (jam)

Efesiensi perontokan adalah banyaknya buah lada yang dapat terontok dari tangkainya. Efisiensi perontokan dapat dihitung dengan persamaan 2.

Efisiensi perontokan $=\frac{L T}{L T+L T T} \times 100 \%(\%)$

keterangan:

LT = Lada terontok (butir)

LTT $=$ Lada tidak terontok (butir)

\section{HASIL DAN PEMBAHASAN}

\section{A. Hasil Perancangan}

Hasil pengukuran menunjukkan bahwa besarnya gaya yang diperlukan untuk merontokkan lada pada mesin perontok adalah 14,7 N. Besarnya torsi hasil perhitungan yang diperlukan pada mesin perontok adalah 1,68 N.m. Hasil perancangan komponen-komponen pada mesin perontok lada adalah daya motor pengukuran 52,75 watt, daya motor terpakai 186,5 watt $(1 / 4 \mathrm{HP})$, daya motor rencana 186,5 watt, diameter poros $10,46 \mathrm{~mm}$, perbandingan transmisi $2: 9$, ukuran puli penggerak $2 \mathrm{inch}$, ukuran puli yang digerakkan 9 inch, jenis sabuk V tipe A, panjang sabuk ukuran 50 inch $(1270 \mathrm{~mm})$, jarak sumbu poros $420,4 \mathrm{~mm}$ dengan jumlah sabuk sebanyak 1 buah.

\section{B. Hasil Pembuatan}

Mesin perontok lada dengan mekanisme silinder perontok berjaring dapat dilihat pada Gambar 4. Secara umum mesin perontok lada yang dibuat hampir sama dengan hasil perancangan awal. Spesifikasi lengkap mesin perontok lada dengan mekanisme silinder berjaring hasil rancang bangun dan konstruksi dapat dilihat pada Tabel 1.

Mekanisme perontok lada dibuat menggunakan kayu berbentuk silinder yang dilapisi jaring nilon. Proses perontokan dilakukan dengan melewatkan buah lada dan tangkainya pada silinder 
perontok yang berputar. Kondisi tersebut menyebabkan buah lada terbentur silinder perontok, sehingga buah lada lepas dari tangkainya. Buah lada yang lepas selanjutnya jatuh melewati pemisah buah dan menuju saluran keluar. Pegas berfungsi sebagai penahan pada pemisah buah, selain itu menjaga agar pergerakan pemisah buah menjadi lebih fleksibel.
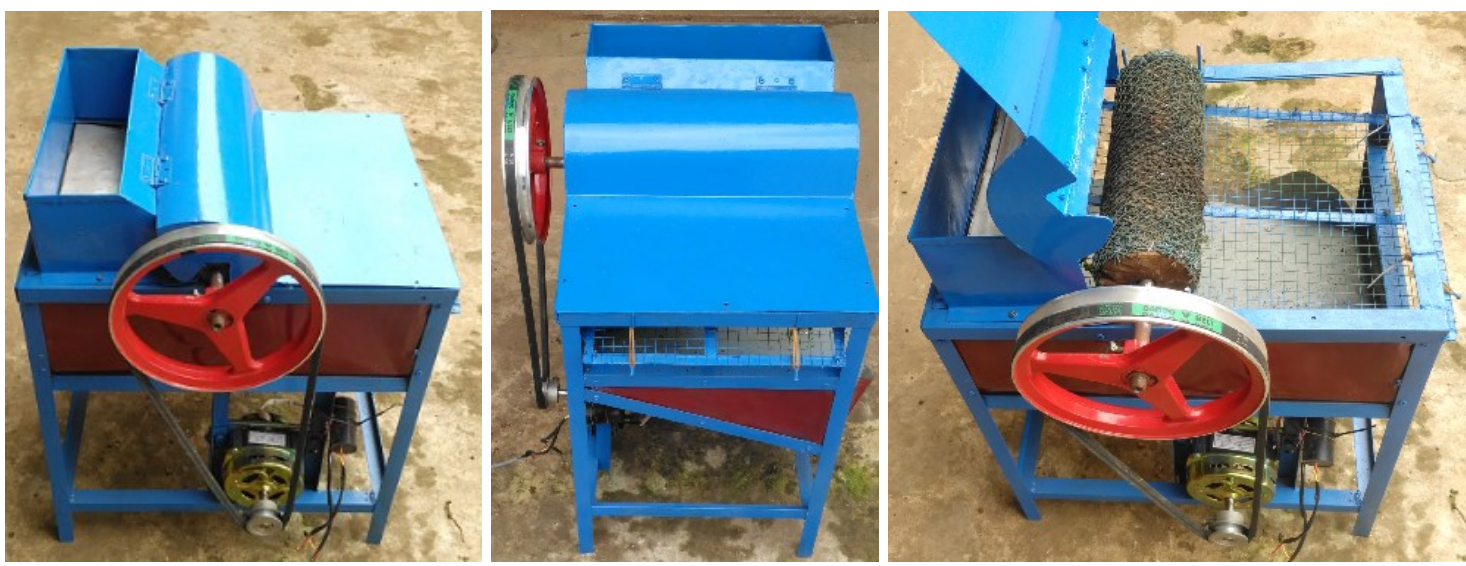

Gambar 4. Mesin perontok lada hasil rancang bangun

Tabel 1. Spesifikasi mesin perontok lada hasil rancang bangun

\begin{tabular}{ll}
\hline Keterangan & Spesifikasi \\
\hline Nama mesin & Perontok lada tipe silinder perontok berjaring \\
Sumber penggerak & Motor listrik 1/4 HP \\
Dimensi & \\
- Panjang & $50,0 \mathrm{~cm}$ \\
- Lebar & $38,5 \mathrm{~cm}$ \\
- Tinggi & $68 \mathrm{~cm}$ \\
Massa total mesin & $12 \mathrm{~kg}$ \\
Kecepatan perontokan & $339 \mathrm{rpm}$ \\
Sistem transmisi & Sabuk V tipe A dan puli \\
Diameter poros silinder perontok & $15 \mathrm{~mm}$ \\
\hline
\end{tabular}

\section{Hasil Pengujian}

Uji kinerja terhadap mesin perontok lada hasil rancang bangun dilakukan pada kapasitas, efisiensi perontokan dan persentase kerusakan buah lada. Hasil pengambilan data awal diperoleh bahwa jumlah rata-rata buah lada pertangkai adalah 54 buah. Data tersebut digunakan untuk menghitung besarnya efisiensi perontokan buah lada pada mesin perontok lada hasil rancang bangun. Variabel bebas dalam pengujian adalah kekuatan tarik pegas pada pemisah buah lada dengan nilai masing-masing $0,19,0,30$ dan $0,45 \mathrm{~kg} / \mathrm{cm}$. Kecepatan putar operasional mesin perontok adalah 339 rpm diukur menggunakan tachometer.

Kapasitas perontokan pada mesin perontok lada dengan mekanisme silinder berjaring dihitung berdasarkan persamaan 1. Hasil uji kinerja terhadap kapasitas perontokan menunjukkan bahwa kekuatan tarik pegas yang terlalu kecil menyebabkan lada mudah melewati silinder perontok, sedangkan kekuatan tarik pegas yang besar menyebabkan lada semakin lama melewati silinder perontok. Bertambahnya kekuatan tarik pegas pada pemisah buah menyebabkan terjadinya penurunan kapasitas perontokan lada. Data lengkap hasil pengujian pada mesin perontok lada dengan mekanisme silinder berjaring dapat dilihat pada Tabel 2.

Tabel 2. Hasil pengujian efisiensi perontokan, persentase kerusakan dan kapasitas mesin

\begin{tabular}{ccccccc}
\hline \multirow{2}{*}{$\begin{array}{c}\text { Kekuatan tarik } \\
\text { pegas }(\mathrm{kg} / \mathrm{cm})\end{array}$} & \multicolumn{2}{c}{ Efisiensi perontokan } & \multicolumn{2}{c}{ Persentase kerusakan } & \multicolumn{2}{c}{ Kapasitas perontokan } \\
\cline { 2 - 7 } & $(\%)$ & SD & $(\%)$ & SD & $(\mathrm{kg} /$ jam $)$ & SD \\
\hline 0,19 & $35,8 \%$ & $6,8 \%$ & $8,8 \%$ & $2,0 \%$ & 117,8 & 3,5 \\
0,30 & $89,5 \%$ & $3,1 \%$ & $16,2 \%$ & $1,3 \%$ & 105,1 & 3,1 \\
0,45 & $97,5 \%$ & $0,9 \%$ & $31,8 \%$ & $4,4 \%$ & 102,9 & 2,7 \\
\hline
\end{tabular}


Hasil pengujian menunjukkan kapasitas tertinggi diperoleh pada kekuatan tarik pegas 0,19 $\mathrm{kg} / \mathrm{cm}$ dengan kapasitas perontokan $117,8 \mathrm{~kg} / \mathrm{jam}$. Pada kekuatan tarik pegas $0,30 \mathrm{~kg} / \mathrm{cm}$ menghasilkan kapasitas perontokan $105,1 \mathrm{~kg} / \mathrm{jam}$ sedangkan pada kekuatan tarik pegas $0,45 \mathrm{~kg} / \mathrm{cm}$ menghasilkan kapasitas perontokan $102,9 \mathrm{~kg} / \mathrm{jam}$.

Efisiensi perontokan lada pada mesin dapat dihitung berdasarkan persamaan 2. Hasil uji kinerja pada efisiensi perontokan lada menunjukkan bahwa kekuatan tarik pegas yang terlalu kecil menyebabkan lada sulit terontok dari tangkainya, sedangkan kekuatan tarik pegas yang besar menyebabkan lada lebih mudah terontok. Namun kekuatan tarik pegas yang besar dapat menyebabkan tingkat kerusakan lada yang tinggi dan begitu pula sebaliknya. Efisiensi perontokan tertinggi diperoleh pada kekuatan tarik pegas $0,45 \mathrm{~kg} / \mathrm{cm}$ dengan efisiensi perontokan 97,5\% namun memiliki tingkat kerusakan yang sangat tinggi yaitu $31,8 \%$. Pada kekuatan tarik pegas $0,30 \mathrm{~kg} / \mathrm{cm}$ terjadi penurunan efisiensi perontokan dan kerusakan masing-masing menjadi 89,5\% dan 16,2\%, sedangkan pada kekuatan tarik pegas $0,19 \mathrm{~kg} / \mathrm{cm}$ menghasilkan efisiensi perontokan $35,8 \%$ dengan persentase kerusakan $8,8 \%$.

Mesin perontok lada hasil rancang bangun dapat meningkatkan kapasitas mesin perontok lada berpenggerak pedal hasil desain Satria dan Suhendra (2014), dengan mengganti sumber penggerak berupa motor listrik 1/4 HP. Pengoperasian mesin perontok disarankan pada kekuatan tarik pegas 0,3 $\mathrm{kg} / \mathrm{cm}$. Berdasarkan kapasitas dan efisiensi perontokan, mesin perontok lada hasil rancang bangun lebih baik dari mesin perontok hasil rancangan Sugianto dan Sukanto (2012) dengan kapasitas 40 $\mathrm{kg} / \mathrm{jam}$ dan efisiensi $80 \%$, namun lebih rendah dari Hidayat dkk (2001) dengan kapasitas 267,46 $\mathrm{kg} / \mathrm{jam}$ dan efisiensi 98,7\%, Yunus (2007) dengan kapasitas $342 \mathrm{~kg} / \mathrm{jam}$ dan efisiensi 97,7\% serta Djajasukmana (2010) dengan kapasitas $600 \mathrm{~kg} / \mathrm{jam}$ dan efisiensi 98,74\%. Namun demikian, keunggulan mesin perontok lada hasil rancang bangun adalah menggunakan motor listrik berdaya kecil, konstruksi silinder perontok sederhana, mudah dibuat dan murah harganya sehingga sangat memungkinkan digunakan oleh petani lada dalam proses perontokan.

\section{KESIMPULAN}

Berdasarkan hasil rancang bangun dan uji kinerja pada mesin perontok lada tipe silinder perontok berjaring dapat dibuat kesimpulan sebagai berikut :

a. Mesin perontok lada tipe silinder perontok berjaring memiliki spesifikasi tenaga penggerak berupa motor listrik 1/4 HP, kecepatan operasional silinder perontok $339 \mathrm{rpm}$, sistem transmisi sabuk V dan puli, massa mesin $12 \mathrm{~kg}$, panjang $50,0 \mathrm{~cm}$, lebar $38,5 \mathrm{~cm}$ dan tinggi $68 \mathrm{~cm}$.

b. Kekuatan tarik pegas pada saringan buah dan tangkai lada sangat menentukan besarnya kapasitas, efisiensi perontokan dan persentase kerusakan pada buah lada. Penambahan nilai kekuatan tarik pegas dapat menurunkan kapasitas mesin, meningkatkan efisiensi perontokan dan persentase kerusakan buah lada.

\section{DAFTAR PUSTAKA}

Djajasukmana R.B. 2010. Teknik Perontokan Lada Menggunakan Alat Perontok Mekanis. Buletin Teknik Pertanian 15(1): 24-27

Hidayat T. Risfaheri dan Nurdjannah N. 2001. Rancang Bangun Alat Perontok Lada Model Aksial. Jurnal Littri .(7)2: 54-59

Mislaini R. 2016. Rancang Bangun dan Uji Teknis Alat Perontok Padi Semi Mekanis Portabel. Jurnal Teknologi Pertanian Andalas. 20(1): 1-8

Satria dan Suhendra. 2014. Mesin Perontok Lada dengan Penggerak Pedal. Lomba Inovasi Teknologi Tepat Guna (TTG) Se-Kabupaten Sambas Tahun 2014. Pemerintah Kabupaten Sambas

Sugianto dan Sukanto. 2012. Mesin Perontok Tangkai Lada Berkapasitas $40 \mathrm{~kg}$ per jam. Jurnal Turbo. (1)2: 95-105

Winarti C. Nurdjannah N. 2007. Pedoman Pengolahan Lada Putih dan Hitam. Badan Penelitian dan Pengembangan Pertanian. Departemen Pertanian

Yunus M.R. 2007. Design and Performance Tests of Simple Thresher for Pepper. Jurnal Riset Industri. 1(2): 96-104 